\title{
PEMANFAATAN ACHANTUS ILICIFOLIUS SEBAGAI PRODUK OLAHAN TEH DALAM RANGKA MELESTARIKAN MANGROVE DI DESA LABUHAN SUMBAWA
}

\author{
Dwi Mardhia ${ }^{* 1)}$, Rahman Firdaus ${ }^{1)}$, Aan Saputra ${ }^{1)}$, Fitri Asriyanti ${ }^{1)}$, Djodi Arya \\ Pratama ${ }^{1)}$ \\ 1)Program Studi Manajemen Sumberdaya Perairan Universitas Samawa \\ Jalan Raya Semongkat No 1 Kampus Bileng Monte, Kabupaten Sumbawa Besar, Nusa \\ Tenggara Barat 84313 \\ *)alamat korespondensi: kemang.kuneng@gmail.com
}

\begin{abstract}
ABSTRAK
Achantus ilicifolius atau dikenal dengan nama Jeruju merupakan salah satu jenis mangrove yang banyak dijumpai di wilayah pesisir Pulau Sumbawa. Fungsi Jeruju adalah sebagai fitoteknologi, yaitu sebagai indikator rusaknya kondisi ekosistem mangrove. Upaya pelestarian Jeruju perlu dilakukan salah satunya dengan memberikan nilai tambah berupa pemanfaatannya sebagai produk olahan teh yang memiliki manfaat bagi kesehatan. Pemanfaatan Jeruju sebagai teh akan memberikan nilai manfaat secara ekonomi, ekologis maupun kesehatan. Kegiatan pengabdian dilakukan kepada ibu-ibu rumah tangga desa Labuhan Sumbawa yang bertujuan untuk menambah pengetahuan dan keterampilan masyarakat Desa Labuhan Sumbawa melalui kegiatan pemanfaatan Jeruju sebagai teh, meningkatkan rasa kepedulian masyarakat terhadap ekosistem mangrove sehingga ekosistem mangrove dapat terjaga, mendorong masyarakat agar dapat menjadi wirausahawan mandiri dengan memanfaatkan daun Jeruju serta mengurangi kerusakan mangrove akibat penebangan secara liar oleh masyarakat. Metode yang digunakan dalam kegiatan ini adalah penyuluhan, pelatihan dan pendampingan pengolahan Jeruju sebagai teh. Hasil kegiatan menunjukkan adanya peningkatan pengetahuan dan keterampilan masyarakat mitra sebesar $43 \%$, adanya peningkatan kesadaran masyarakat dalam melestarikan ekosistem mangrove serta terciptanya peluang usaha teh daun Jeruju.
\end{abstract}

Kata kunci: Achantus ilicifolius, Jeruju, mangrove, teh 


\section{PENDAHULUAN}

Desa Labuhan Sumbawa merupakan salah satu desa yang ada di kecamatan Labuhan Badas, Kabupaten sumbawa, Provinsi Nusa Tenggara Barat, desa ini merupakan satu dari tujuh desa dan kelurahan yang berada di Kecamatan Labuhan Badas. Penduduk desa Labuhan Sumbawa sebagian besar bermata pencaharian sebagai nelayan, PNS dan swasta. Secara ekonomi rasio beban tanggungan di kecamatan Labuan Badas 55,08\%, ini berarti tiap 100 penduduk produktif harus menanggung 55 penduduk tidak produktif. Besarnya angka rasio beban tanggungan merupakan salah satu faktor penghambat pembangunan ekonomi, karena sebagian pendapatan yang sebenarnya dapat ditabung yang kemudian diinvestasikan bagi pembangunan terpaksa harus dikeluarkan untuk mencukupi kebutuhan primer penduduk yang tidak produktif. Berdasarkan hal tersebut, perlu adanya mata pencaharian lain yang dapat dilakukan oleh masyarakat Kecamatan Labuhan Badas dalam memenuhi kebutuhan hidup dan meningkatkan pendapatan melalui pemanfaatan sumber daya potensi yang ada secara optimal.

Pesisir Labuhan Sumbawa merupakan salah satu lokasi di Kabupaten Sumbawa yang memiliki potensi mangrove yang tinggi akan tetapi masyarakat sekitar belum mampu memanfaatkan potensi yang ada untuk meningkatkan pendapatan. Masyarakat masih menganggap hutan mangrove merupakan sumberdaya yang kurang potensial secara ekonomi sehingga pemanfaatan yang ada adalah menebang mangrove sebagai kayu bakar, hal ini menyebabkan terjadinya kerusakan hutan mangrove di daerah Labuhan Sumbawa mencapai 35 \%. Apabila pemanfaatan tidak ramah lingkungan ini dibiarkan maka kerusakan ekosistem mangrove akan meningkat setiap tahunnya sehingga secara tidak langsung memberikan dampak terhadap penurunan kualitas dan kuantitas ekosistem mangrove serta meningkatnya abrasi pantai. Oleh karena itu, perlu dilakukan upaya-upaya yang dapat menyelamatkan ekosistem mangrove. Salah satunya ialah dengan memberikan nilai ekonomi langsung terhadap ekosistem mangrove. Selama ini, masyarakat belum mengetahui manfaat ekonomi secara langsung dari ekosistem mangrove, sehingga dianggap tidak potensial.

Desa Labuhan Sumbawa memiliki potensi mangrove jenis Achantus illicifolius (Jeruju) yang sangat melimpah. Tumbuhan ini hidup pada zona menengah sampai belakang pada ekosistem mangrove, 
yaitu daerah yang dipengaruhi pasang surut air laut dan biasanya mendapat pasokan air tawar lebih banyak (Prayogo et.al., 2015). Masyarakat Labuhan Sumbawa belum sadar bahwa hutan mangrove mempunyai manfaat yang sangat besar bagi kehidupan mereka. Pemanfaatan tanaman mangrove ini bertujuan untuk menambah pendapatan ekonomi masyarakat, selain itu tujuan pemanfaatan produk mangrove yaitu untuk memberikan kesadaran pemanfaatan kepada masyarakat bahwa hutan mangrove mempunyai banyak manfaat dan mengajak masyarakat untuk melestarikan hutan mangrove khususnya pengolahan daun Jeruju (Achantus illicifolius) menjadi produk olahan Teh Mangrove (Irawanto et.al., 2015).

Pengolahan teh mangrove ini sangat efektif untuk dikembangkan di Desa Labuhan Sumbawa karena sangat sesuai dengan kebiasaan masyarakat yang selalu mengkonsumsi teh atau kopi setiap pagi sebelum melakukan aktivitas sehari-hari dan adanya kebiasaan selalu menjamu tamu dengan menyajikan minuman teh. Dengan adanya teh mangrove masyarakat mempunyai alternatif usaha lain untuk menambah pendapatan masyarakat tersebut. Teh mangrove dengan merk Teman DJ merupakan usaha teh yang sudah diproduksi oleh mahasiswa program studi Manajemen Sumberdaya Perairan Universitas Samawa melalui pendanaan KBMI 2019. Tim mahasiswa beserta dosen pembimbing mencoba memberikan pemahaman kepada masayrakat melalui kegiatan pendampingan untuk secara bersama-sama menjaga kelestarian mangrove khususnya jenis Jeruju.

Masyarakat Desa Labuhan Sumbawa belum mengetahui manfaat ekonomi secara langsung dari mangrove terutama jenis Achantus illicifolius sehingga menyebabkan mangrove manjadi ekosistem yang diabaikan dan cenderung dianggap tidak potensial. Hal tersebut berdampak pada tingginya penebangan hutan mangrove. Tidak adanya pemanfaatan nilai ekonomi mangrove disebabkan sebagian besar masyarakat belum memiliki pengetahuan dan keterampilan dalam mengolah mangrove menjadi produk yang bernilai ekonomi seperti teh mangrove dari daun mangrove jenis Achantus illicifolius.

Program pengabdian ini bertujuan untuk: (1) Menambah pengetahuan dan keterampilan masyarakat Desa Labuhan Sumbawa melalui kegiatan pemanfaatan Jeruju sebagai teh; (2) Meningkatkan rasa kepedulian masyarakat terhadap ekosistem mangrove sehingga ekosistem mangrove dapat terjaga; 
(3) Mendorong masyarakat agar dapat menjadi wirausahawan mandiri dengan memanfaatkan daun Jeruju; (4) Mengurangi kerusakan mangrove akibat penebangan secara liar oleh masyarakat.

\section{METODE KEGIATAN}

\section{Tempat dan Waktu}

Kegiatan ini dilaksanakan di Desa Labuhan Sumbawa Kecamatan Labuhan Badas. Pelaksanaan kegiatan dilakukan pada Bulan Mei 2019.

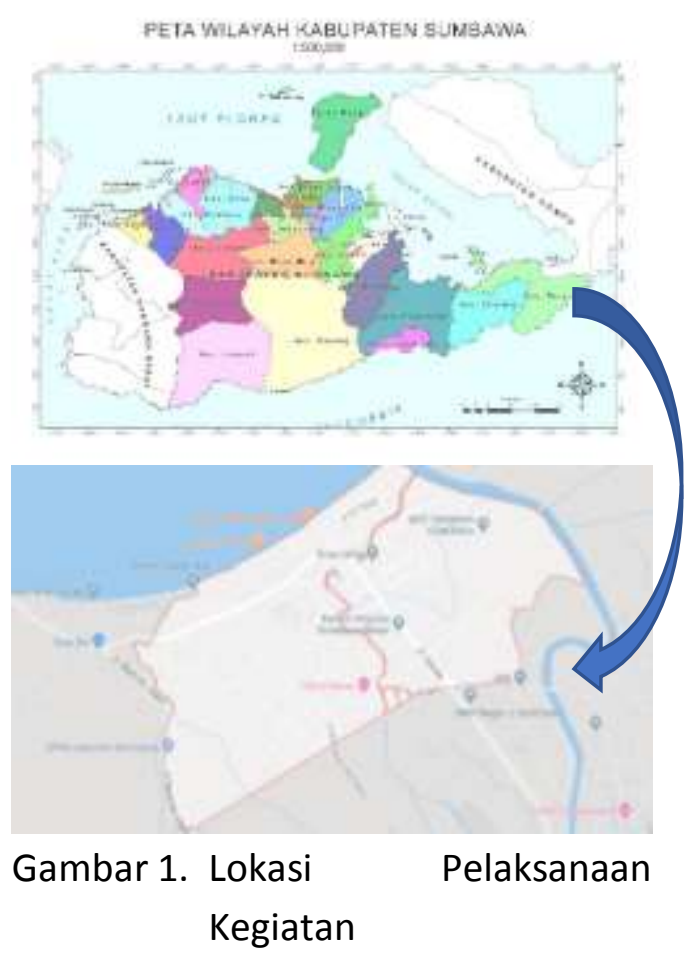

\section{Alat dan Bahan}

Alat dan bahan yang digunakan pada kegiatan pelatihan dan pendampingan pengolahan daun mangrove menjadi teh meliputi: Daun Jeruju (Achantus illicifolius), Air, Kompor, Saringan, Oven, Pisau, Baskom, Gunting, Nampan, Talenan, Alas penjemur, Sendok dan wajan.
Tahapan dan Metode Pelaksanaan Kegiatan

Kegiatan pelatihan dan pendampingan pengolahan daun mangrove menjadi teh ini terdiri atas beberapa tahapan yaitu:

\section{1) Sosialisasi dan Perizinan}

Sosialisasi dan perijinan dilakukan untuk menginformasikan dan mensosialisasikan rencana kegiatan serta menyepakati waktu dan tempat pelaksanaan kegiatan dengan kelompok masyarakat sasaran. Kegiatan sosialisasi awal dilakukan dengan pemerintah Desa Labuhan Sumbawa pada waktu dua minggu sebelum rencana pelaksanaan kegiatan. Tujuan dari sosialisasi ini ialah untuk menginformasikan serta mengurus perijinan kepada pemerintah Desa untuk pelaksanaan kegiatan pengabdian masyarakat . Pada tahap sosialisasi dengan pihak pemerintah desa juga dilakukan persiapan kegiatan meliputi identifikasi jumlah dan nama peserta penyuluhan dan pelatihan serta penentuan tempat dan lokasi pelaksanaan kegiatan.

\section{2) Kegiatan Penyuluhan dan} Pelatihan

Kegiatan penyuluhan ini dilakukan pada hari sabtu tanggal 4 Mei 2019 dan bertempat di aula kantor Desa Labuhan Sumbawa. Kegiatan penyuluhan diikuti oleh 30 peserta ibu-ibu rumah tangga dan ibu-ibu 
PKK Desa Labuhan Sumbawa. Pada

kegiatan penyuluhan, peserta

diberikan penjelasan secara

teoritis mengenai manfaat ekologi

dan ekonomi mangrove, pengolahan daun mangrove

menjadi Teh serta peluang usaha teh jeruju. Metode yang digunakan dalam penyuluhan ini yaitu penjelasan tentang teknik dalam pengolahan daun mangrove jenis Jeruju (Achantus illicifolius) menjadi Teh. Selain penjelasan tentang teknik pengolahan daun mangrove, juga dilakukan tanya jawab dengan kelompok masyarakat ibu-ibu rumah tangga serta dilakukan pembagian kuisioner (Pre test dan Post test) kepada peserta kegiatan untuk mengetahui tingkat pemahaman masyarakat sebelum dan setelah kegiatan penyuluhan dan pelatihan dilaksanakan (Mardhia dan Wartiningsih, 2018).

3) Pelatihan Pengolahan Daun Mangrove

Pada kegiatan ini peserta diberikan bekal untuk mengetahui bagaimana cara mengolah daun mangrove menjadi Teh Mangrove jenis Jeruju (Achantus illicifolius) yang bernilai jual. Adapun cara pengolahan yang diberikan kepada kelompok masyarakat sasaran adalah sebagai berikut:

1. Persiapan alat

Pada tahap periapan alat dijelaskan tentang alat yang dibutuhkan dalam pembuatan Teh mangrove daun Jeruju termasuk teknik pembuatan Teh mangrove daun Jeruju meliputi tiga teknik yaitu penjemuran (memanfaatkan sinar matahari), metode sangrai dan metode menggunakan oven.

2. Persiapan bahan

Persiapan bahan meliputi pemetikan daun jeruju yang diambil di sekitar ekosistem mangrove yang ada di desa Labuhan Sumbawa dengan cara daun jeruju dipetik dengan menggunakan alat bantu berupa gunting atau pisau dikarenakan daun jeruju memiliki duri disetiap helai daun. Daun jeruju yang dipetik adalah daun jeruju dari pucuk pertama sampai pucuk ketiga. Setelah daun jeruju dipetik, kemudian daun jeruju dibersihkan dari durinya menggunakan gunting untuk memudahkan saat proses pembersihan. Setelah pembersihan duri dilakukan pemisahan daun jeruju dengan tulang daun. Kemudian, daun jeruju diiris tipis-tipis. 


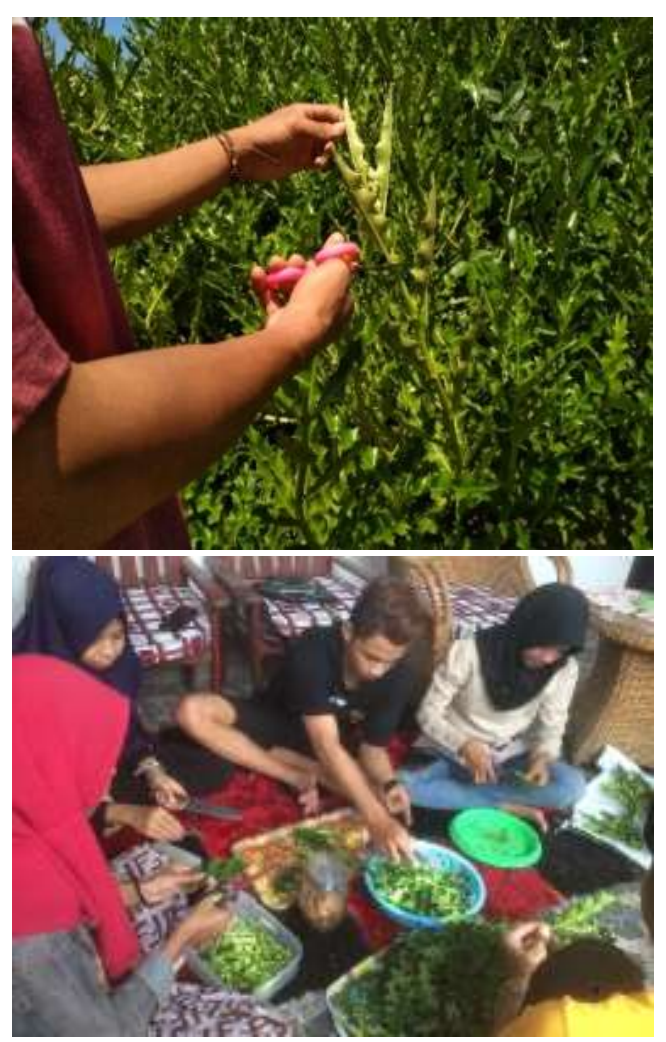

Gambar 2. Persiapan Bahan

3. Pengolahan daun Jeruju menjadi teh

Pada kegiatan penyuluhan, Tim memberikan penjelasan kepada masyarakat bahwa pengolahan teh jeruju menggunakan 3 metode yaitu:

a. Metode penjemuran

Pada metode penjemuran daun jeruju yang sudah diiris tipistipis diletakkan didalam wadah kemudian dilakukan proses penjemuran dibawah sinar matahari selama \pm 1-2 hari dengan sinar matahari yang cukup terik.

b. Metode sangrai

Pada metode sangrai daun jeruju yang sudah diiris tipistipis disangrai di atas api kecil \pm
10-15 menit dan dilakukan pengadukan secara terus menerus agar daun jeruju kering secara merata. Pada metode sangrai memiliki kelebihan waktu lebih cepat tetapi kelemahan pada metode sangrai memerlukan kontrol lebih dalam hal pengadukan dan temperatur pemanasan.

c. Metode oven

Pada metode pengovenan daun jeruju yang sudah diiris tipis diletakkan didalam wadah kemudian dimasukan kedalam oven dengan suhu $150{ }^{\circ} \mathrm{C}$ selama \pm 25 menit.
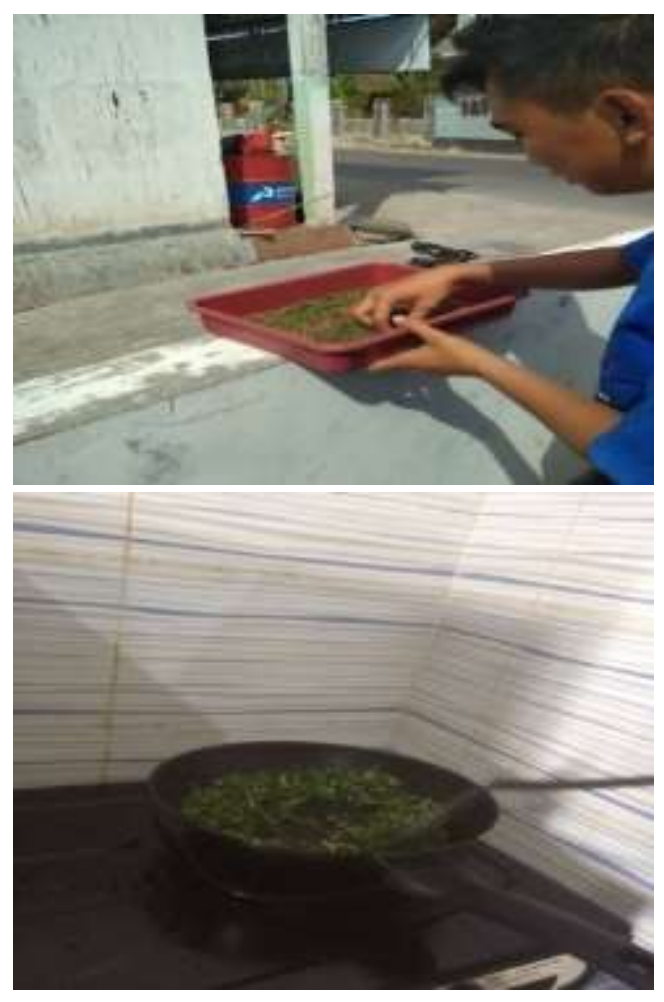


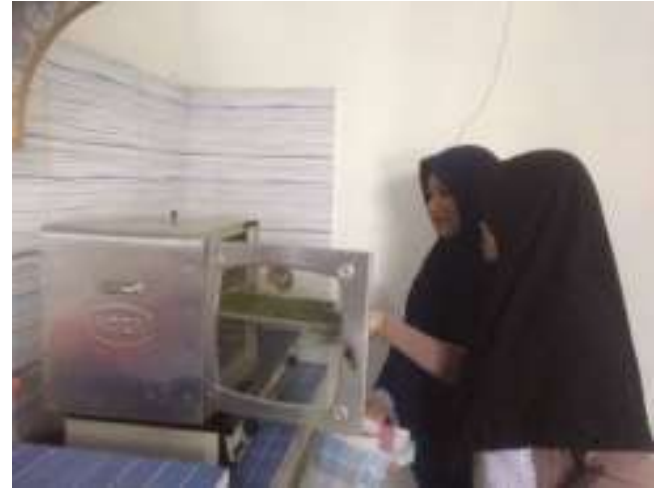

Gambar 3. Metode Pengeringan Teh Jeruju

4. Pengemasan (packing)

Memberikan contoh teknik pengemasan produk agar menarik dan memiliki nilai jual yang tinggi.

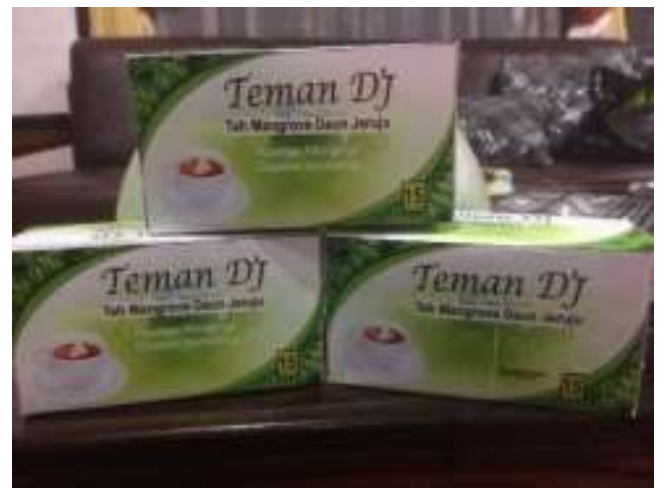

Gambar 4. Kemasan Teh Jeruju

5. Penyuluhan tentang potensi usaha Teh mangrove daun jeruju

Pada kegiatan ini disampaikan materi tentang potensi usaha teh mangrove daun jeruju sebagai alternatif mata pencaharian dan oleh-oleh khas Desa Labuhan Sumbawa yang diharapkan dapat meningkatkan pendapatan dan kesejahteraan masyarakat Desa Labuhan Sumbawa

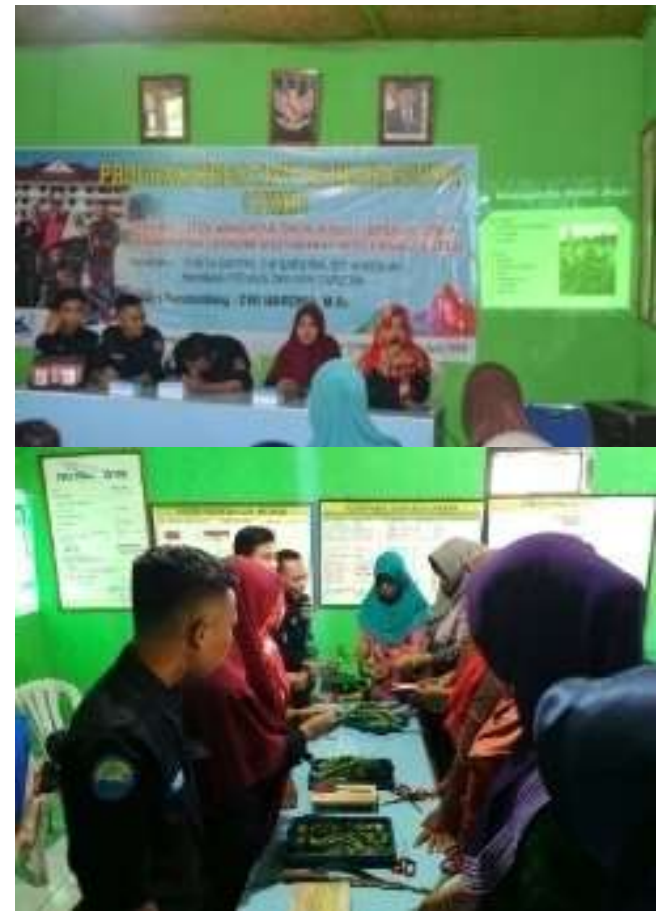

Gambar 5. Suasana Pelaksanaan Kegiatan Penyuluhan dan Pelatihan PKMM

\section{HASIL DAN PEMBAHASAN}

Respon Pemerintah Desa dalam Kegiatan Sosialisasi dan Perijinan

Tahap perijinan dan sosialisasi awal dilakukan dua minggu sebelum kegiatan penyuluhan dan pelatihan. Perijinan dan sosialisasi awal dilakukan secara tertulis melalui surat menyurat dan secara langsung dengan menemui Kepala Desa Labuhan Sumbawa. Pada kegiatan penyampaian gambaran umum kegiatan pengabdian, pemaparan tujuan dan diskusi dengan Kepala Desa Labuhan Sumbawa diperoleh beberapa tanggapan terhadap kegiatan pengabdian yang akan dilakukan di wilayah kerjanya, diantaranya yaitu: Kepala Desa 
Labuhan Sumbawa sangat berterimakasih terhadap kegiatan pengabdian yang dilakukan oleh Universitas Samawa karena merupakan kebutuhan yang sangat diperlukan mengingat masalah tidak adanya pemanfaatan atau pengolahan daun mangrove jenis jeruju menjadi teh merupakan masalah yang sampai saat ini belum mendapat solusi penanganan yang tepat, sehingga melalui kegiatan ini diharapkan mampu menjadi solusi tepat bagi permasalahan yang ada di desa Labuhan Sumbawa. Disamping itu kepala desa Labuhan Sumbawa berharap agar jalinan silaturrahmi antara Universitas dan pemerintah Desa Labuhan Sumbawa tidak berhenti sampai kegiatan ini berakhir.

\section{Hasil Kegiatan Monitoring dan Evaluasi}

Tahap evaluasi pelaksanaan program bertujuan untuk mengukur tingkat keberhasilan kegiatan pengabdian yang diterapkan. Tahap evaluasi meliputi evaluasi tiap tahap pelaksanaan kegiatan dan evaluasi secara keseluruhan. Evaluasi tiap tahap kegiatan dilakukan guna melihat tingkat keberhasilan dan menjadi bahan pertimbangan untuk kegiatan berikutnya. Evaluasi keseluruhan dilakukan setelah program atau kegiatan pengabdian selesai dilaksanakan. Evaluasi yang dilakukan meliputi:

a) Tingkat partisipasi peserta pada kegiatan.

Evaluasi terhadap tingkat partisipasi ini dilakukan pada rangkaian kegiatan dengan cara memonitoring dan mengevaluasi jumlah kehadiran peserta pelatihan. Kehadiran peserta kegiatan penyuluhan dan pelatihan pembuatan teh Jeruju adalah sesuai dengan permintaan tim yaitu sebanyak 30 orang dan peserta mengikuti kegiatan sampai selesai.

b) Tingkat pengetahuan peserta Evaluasi ini akan dilakukan pada tahap awal dan akhir kegiatan pelatihan untuk meninjau tingkat pengetahuan peserta kegiatan sebelum dan setelah diadakannya kegiatan pengabdian dengan metode kuisioner dan kuis. Dari hasil evaluasi terhadap pengisian kuisioner pada pelaksanaan Pre test dan Post test diketahui bahwa terdapat peningkatan pengetahuan peserta terhadap materi penyuluhan dan pelatihan. Hal ini menandakan bahwa penyampaian materi oleh tim dapat dipahami dengan baik oleh peserta. Hasil analisis pre test dan post test peserta adalah sebagai

berikut: 
Tabel 1. Hasil Pre Test dan Post Test

\begin{tabular}{|c|c|c|c|}
\hline Peserta & $\begin{array}{l}\text { Nilai } \\
\text { Pre } \\
\text { test }\end{array}$ & $\begin{array}{l}\text { Nilai } \\
\text { Post } \\
\text { test }\end{array}$ & $\begin{array}{c}\text { Peningkatan } \\
(\%)\end{array}$ \\
\hline 1 & 9 & 36 & 27 \\
\hline 2 & 0 & 73 & 73 \\
\hline 3 & 18 & 73 & 55 \\
\hline 4 & 18 & 82 & 64 \\
\hline 5 & 0 & 82 & 82 \\
\hline 6 & 0 & 100 & 100 \\
\hline 7 & 18 & 100 & 82 \\
\hline 8 & 64 & 100 & 36 \\
\hline 9 & 9 & 100 & 91 \\
\hline 10 & 9 & 100 & 91 \\
\hline 11 & 18 & 100 & 82 \\
\hline 12 & 18 & 100 & 82 \\
\hline 13 & 0 & 100 & 100 \\
\hline 14 & 0 & 100 & 100 \\
\hline 15 & 18 & 100 & 82 \\
\hline 16 & 0 & 100 & 100 \\
\hline 17 & 0 & 100 & 100 \\
\hline 18 & 27 & 100 & 73 \\
\hline 19 & 9 & 100 & 91 \\
\hline 20 & 0 & 100 & 100 \\
\hline 21 & 0 & 100 & 100 \\
\hline 22 & 18 & 100 & 82 \\
\hline 23 & 18 & 100 & 82 \\
\hline 24 & 0 & 100 & 100 \\
\hline 25 & 18 & 100 & 82 \\
\hline 26 & 18 & 100 & 82 \\
\hline 27 & 0 & 100 & 100 \\
\hline 28 & 18 & 100 & 82 \\
\hline 29 & 0 & 100 & 100 \\
\hline 30 & 9 & 100 & 91 \\
\hline
\end{tabular}

rata-

\begin{tabular}{ccrr} 
rata & 11 & 95 & 84 \\
\hline (Sumber: Data Primer diolah, 2019) \\
Hasil $\quad$ evaluasi & terhadap \\
tingkat & pengetahuan & peserta
\end{tabular}

menunjukkan bahwa sebelum pelaksanaan kegiatan, pengetahuan peserta masih sangat minim terhadap daun Jeruju maupun pemanfaatannya. Ini terlihat dari hasil pre test yang menunjukkan $97 \%$ peserta hanya mampu menjawab dengan benar paling banyak 3 pertanyaan dari 11 pertanyaan. Hasil post test menunjukkan adanya peningkatan pemahaman dari peserta yaitu sebanyak $84 \%$ peserta mampu menjawab dengan benar semua pertanyaan.

a) Tingkat keterampilan peserta dalam mengolah daun jeruju menjadi teh

Evaluasi dilakukan dengan metode pengamatan secara langsung pada masing-masing individu peserta pelatihan. Evaluasi keterampilan meliputi keterampilan dalam mempersiapkan bahan (menghilangkan duri daun jeruju, memisahkan daun dari tulang daun, mengiris daun jeruju), keterampilan mengolah daun jeruju menjadi teh baik dengan metode penjemuran, metode sangria dan metode oven. Hasil evaluasi menunjukkan peserta sangat terampil dalam mengolah Jeruju sebagai teh.

b) Evaluasi akhir menunjukkan bahwa kegiatan pengabdian ini membuka wawasan masyarakat terhadap Jeruju. Ibu PKK mengalami kesulitan dalam 
melanjutkan usaha teh Jeruju karena masih kurangnya pengetahuan masyarakat luas tentang khasiat teh jeruju. Hasil evaluasi tersebut kemudian ditanggulangi dengan adanya komitmen dari pemerintah desa untuk melakukan kegiatan sosialisasi secara menyeluruh dan terus menerus sehingga masyarakat mau mengkonsumsi teh Jeruju

\section{Potensi Keberlanjutan}

Beberapa potensi dari hasil kegiatan ini ialah:

a) Potensi hasil/manfaat dari publikasi kegiatan

Publikasi kegiatan yang telah dilakukan di media cetak dan online yang telah dibaca oleh masyarakat banyak berpotensi merubah pola pikir masyarakat terhadap mangrove jenis Jeruju sehingga dengan adanya perubahan pola pikir tersebut, ekosistem mangrove di Kabupaten Sumbawa atau daerah lainnya dapat terselamatkan. Adanya publikasi ini juga berpotensi membuka pikiran masyarakat dalam berkreasi untuk pengolahan mangrove.

b) Potensi hasil keberlanjutan ekosistem
mangrove

Adanya penyuluhan mengenai ekosistem mangrove serta pelatihan dalam pembuatan olahan daun Jeruju berpotensi untuk menjaga keberlanjutan ekosistem mangrove di pesisir.

c) Potensi hasil untuk keberlanjutan sosial-ekonomi masyarakat

Olahan mangrove berupa teh mangrove berpotensi untuk menjadi usaha baru yang dapat meningkatkan taraf hidup dan perekonomian masyarakat. Dengan adanya peningkatan ekonomi secara otomatis dapat meningkatkan kesejahteraan dan satus sosial masyarakat pesisir misalnya mengurangi jumlah pengangguran dan peningkatan status sosial lainnya.

\section{KESIMPULAN DAN SARAN}

Dari pelatihan pengolahan mangrove jenis Jeruju maka hasil yang dicapai adalah terdapat peningkatan pengetahuan dan keterampilan masyarakat mitra didalam pemanfaatan daun mangrove jenis Jeruju (Achantus illicifolius) menjadi teh sebanyak $83 \%$ dan adanya kesadaran masyarakat untuk melestarikan ekosistem mangrove.

UCAPAN TERIMA KASIH

Tim KBMI mengucapkan terima kasih kepada Direktorat Jenderal Pembelajaran dan Kemahasiswaan KEMENRISTEKDIKTI yang telah 
mempercayai dan membiayai kegiatan Program Kompetisi Bisnis Mahasiswa Indonesia (KBMI). Penulis juga mengucapkan terima kasih kepada Lembaga Penelitian dan Pengabdian Masyarakat (LPPM) Universitas Samawa dan Pemerintah Desa Labuhan Sumbawa yang telah memfasilitasi kegiatan ini sehingga dapat terlaksana dengan baik.

\section{DAFTAR PUSTAKA}

Irawanto $\mathrm{R}$, Ariyanti EE, Hendrian R. 2015. Jeruju (Acanthus ilicifolius) : Biji, Perkecambahan dan Potensinya. Jurnal Penelitian. UPT Balai konservasi Tumbhan Kebun Raya, Purwodadi. Volume 1 Nomor 5 Halaman 1011-1018
Prayogo E, Agus Purwoko A, Hartini KS. 2015. Analisis Finansial Pemanfatan Dan Pengolahan Daun Jeruju (Acanthus Ilicifolius L) Menjadi Berbagai Produk Olahan (Financial Analysis of utilization and Processing of Jeruju Leaves (Acanthus ilicifolius L) Becomes Various Products). Tesis. Universitas Sumatera Utara, Medan

Mardhia D, Wartiningsih A. 2018. Pelatihan Pengolahan Sampah Skala Rumah Tangga di Desa Penyaring, Jurnal Pendidikan dan Pengabdian Masyarakat UNRAM, 1(1): 88-96. 